\title{
WHEN TIME AND PLACE AVAIL: WHITMAN'S WRITTEN ORATOR RECONSIDERED
}

\author{
JAKE ADAM YoRK
}

"It avails not, time nor place-distance avails not. . . ."
"Whatever it is, it avails not—-distance avails not, and place avails not. . .."

So WhitMan INSISTs in "Crossing Brooklyn Ferry." And whatever else they do, these insistences, these denials, militate against another denial - the denial of proximity to future generations, of self to other. But to many critics, it seems, one denial must be exchanged for the other. Most readings of the poem's argument conclude that being in one time means not being in another, that being is also barrier, and that connection between or across times means that one or more of the states of being must be perforated, dismantled, transcended, or otherwise abrogated.

For example, James E. Miller, Jr., writes that the poem is a drama of "transcendence" that "lifts" the poet and "many diverse people" "beyond the reach of space and time," and elsewhere expands on Whitman's "triumph over space and time." Paul Orlov discusses the poem as "a timeless voyage of being," James Gargano as the "everlasting" or "transcendentalist" "moment." Richard Pascal finds Whitman arguing that "the conditions of time and space can be transcended." And even Roger Gilbert's decidedly linguistic investigation of the poem finds Whitman attempting to cross over into an "absolute, autonomous present" that escapes time and, therefore, death. ${ }^{2}$

In every case, Whitman somehow escapes time, his time, and the poem escapes its full context. Poet and poem persist as signs of desire outside the systems within which they were first significant. And, alienated from their original context, the phenomena of the poems and of the poet become susceptible to grounding in the schema of contemporary scholars. So scholars as different as Mark Bauerlein and Tenney Nathanson advance critiques of Whitman's oral modes and desires by sifting them through a Derridean screen. ${ }^{3}$ While Bauerlein and Nathanson do deal with palpable tensions in Whitman's work, between oral and scriptural modes, each presses those tensions into the matrices of contemporary linguistic thought and so turns tension into contradic- 
tion. Bauerlein cannot but condescend: "What Whitman wanted most he could not have." ${ }^{4}$ Bauerlein does qualify his observation, noting that Whitman "knew" he could not have what he most wanted-a mode of writing filled with the presence of speech. ${ }^{5}$ But why would Whitman continue to desire and to expend so much effort toward the fulfillment of this desire, if he knew it could not be fulfilled?

Why would Whitman build "Crossing Brooklyn Ferry" toward a moment of mutual presence between speaker and auditor that makes good the declaration that "It avails not, time nor place-distance avails not"? Why establish immediacy in the eighth section?

What gods can exceed these that clasp me by the hand, and with voice I love call me promptly and loudly by my nighest name as I approach?

What is more subtle than this which ties me to the woman or man that looks in my face?

Which fuses me into you now, and pours my meaning into you? (11. 95-97)

Here, the entire drama of distance and its bridging coalesces and resolves. Approach ends in clasping, in tying, fusing, and mixture. Each verb posits a greater immediacy than the one before, and at last speaker and auditor or reader share a single temporal frame and verb tense: "We understand then do we not?" (1.98). Speaker and auditor or reader exist together in a space of mutual understanding and are present to one another in the verb itself - in what may be Whitman's strongest declaration of presence. In the concluding lines of "Song of Myself" Whitman locates himself "under your boot-soles" (1. 1346, emphasis added); here he is with and into the second person. So why, again, would Whitman build this poem, which Thoreau regarded as the gem of the 1856 Leaves of Grass, and which Whitman accorded a separate section to in future editions - why would Whitman build this poem to a moment of mutual presence if, as Bauerlein remarks, he knew such presence was impossible? Is Whitman as delusional as Bauerlein's treatment suggests?

Alienated from his contexts, Whitman might seem deluded in hoping for a written speech. His collisions of oral and scriptural modes may seem futile. Yet, there is in the culture of nineteenth-century American oratory ample precedent for Whitman's hope and for the practices he undertakes to realize his hope-precedent that remains unexplored in all the work dedicated to Whitman's fascination with oratory.

Whitman's own comments about the orators he admired and his own indications of literary genealogy direct us more to Emerson, Elias Hicks, and Father Edward Taylor than to any others. And the usefulness of the scholarship that has addressed Whitman's debts and connections to these writers is testimony enough to the value of these indications. Yet it seems that no Whitman scholar has ventured far outside this group of oratorical ancestors to consider the effects others may have had, directly or indirectly, on Whitman's practice. This is striking, es- 
pecially if F. O. Matthiessen is right in stating that "oratory was then the basis for other forms of writing, and its modes of expression left a mark on theirs."

Studies such as C. Carroll Hollis's Language and Style in Leaves of Grass, have illuminated Whitman's "marks"-those stylistic affinities he has with orators such as Martin Farquhar Tupper. ${ }^{7}$ But there is more to oratory than cadence, than style, than persona. There is argument, the large form, and there are theatrical and public gestures written in the liturgies within which addresses were made. And some of these items seem to explain both Whitman's hope for a written orality and his attempts to produce it. In particular, the epideictic or commemorative oratory of Daniel Webster and Edward Everett strongly underwrites Whitman's hope and practice, especially if we consider not only the texts but the performances and publication histories of these orations.

Daniel Webster's 1825 address at the inception and dedication of the Bunker Hill Monument is the most instructive case. The argument of the address performs and encourages mutual conversions of speech and writing - speech into writing and writing into speech, giving speech the physical solidity of writing and writing the presence of speech-and its stages of publication repeat the performance and encouragement, so that the text and its history provide precedents for Whitman's "written oratory." Within the address, the commemorative action depends on the mutual conversion and confusion of speech and writing. From the opening, the power of the spoken word is imagined physically. Webster first declares that the "purpose" of the commemorative assembly has "made a deep impression on [the] hearts" of the gathered. ${ }^{8}$ So the nonor metaphysical event, which includes the address, and the even less corporeal purpose of the event, are imaged, given body, and the substance of the invisible is made visible and more palpable. This fusion of hearing, sight, and touch is an impressive union that figures the national work of the occasion. But more immediately to the point, this synaesthesia works to embody that purpose and the idea of nation being built at Bunker Hill: expression is impressed.

This is especially clear when Webster turns to consider the monument directly. Webster first emphasizes the power of the physical act and of the physical object, speaking of the monument's "massive solidity" as a "fit emblem" of events and of gratitude, and recognizing the aim of the Bunker Hill Society to erect "some . . . durable monument to the memory of the early friends of American Independence" (emphasis added). But he complicates this directly when he declares: "We know ... that the record of illustrious action is most safely deposited in the universal remembrances of mankind. ... We know . . . that no structure, which shall not outlive the duration of letters and knowledge among men, can prolong the memorial." For Webster, human memory is stronger than the physical record of remembrance, stronger than both monu- 
ment and scripture, and so is to be preferred. And yet scripture is required to advance human memory. The monument serves "to foster a constant regard for the principles of the Revolution" and "mark[s] a spot which must for ever be dear" and in marking that spot "proclaim[s] the magnitude and importance of that event to every class and every age" so that "infancy may learn the purpose of its erection from maternal lips, and that weary and withered age may behold it,"and be solaced by the recollections which it suggests." So the marker, inasmuch as it expresses the understanding of its erectors, precedes and promulgates the impression on later generations in which it produces understanding and national memory; the physical sign precedes and produces the mental state. ${ }^{9}$

Webster extends and accelerates this process near the middle of the address when he posits the eventual destruction of the monument and its replacement: "This monument may moulder away; . . . but thy memory shall not fail!" The monument, previously imagined as a potential surface for inscription, must be replaced by a heart duly impressed, which will then locate the "principles of the Revolution." So: "Wheresoever among men a heart shall be found that beats to the transports of patriotism and liberty, its aspirations shall be to claim kindred with thy spirit!" The heart, the seat of felt memory, will incorporate and supersede the marker. Webster encourages again this transposition of memorial in his close, when he directs his auditors: "let the sacred obligations which have devolved on this generation, and on us, sink deep into our hearts." Again, the insubstantial-obligation, memory - is ultimately substantiated in the human heart, the human memory; men and women take the place of the monument begun before them, each acting as a block, a surface, which, unified, fulfill Webster's demand that the "country itself become a vast and splendid monument ... upon which the world may gaze with admiration for ever!" Webster encourages his auditors to witness the inscription the monument makes upon the landscape, the translation of the spoken word and the spirit expressed thereby into the physical sign, and then to repeat this translation, incorporating the sign and writing upon their hearts with it. ${ }^{10}$

With the publication of the address immediately following the event, this process extends indefinitely, as the word made sign made word again is launched as text into the world where its readers may translate it again into word. And this is exactly what many people did. According to Irving Bartlett, "entire generations of American schoolboys were soon reciting it in classrooms across the country." 11 They were translating it back into speech. And so they were learning it, as were many adults, across America. When Webster spoke at Bunker Hill in 1825, there were, according to Craig R. Smith, approximately twenty thousand persons in attendance. ${ }^{12}$ When Webster returned in 1843 to speak at the 
completion of the monument, the crowd was estimated at one hundred thousand persons, to whom, according to Edwin Whipple, the terms of Webster's 1825 address were "household words."13 Print publication had increased the reception of the 1825 address by at least five-hundred percent.

This means that many more Americans read the address in print than had actually heard it first delivered. And this was not uncommon. Pauline Maier has demonstrated in her American Scripture that many Americans had first knowledge of Independence through the papers and that many others had the news via the public proclamation of a document originally written. The public pronouncements, such as the one in Philadelphia, were deeply affective and no less real for the document's having an origin in another mode (we have an affective measure in the Liberty Bell). ${ }^{14}$ The addresses of Webster, Everett, and others followed the same pattern: written first, orated from memory, then disseminated as printed speech, sometimes re-orated, often to great effect. Similar ceremonies at Danvers, Massachusetts, on April 19, 1835; Concord, Massachusetts, on July 4, 1837; Bunker Hill in June 1843; Danbury, Connecticut, in April 1854; Worcester, Massachusetts, in April 1861; and at Doylestown, Pennsylvania, in December 1861, were advertised in much the same way, in newspaper accounts and in pamphlets that provided a detailed liturgy of events and texts of all oral deliveries. ${ }^{15}$ Functionally, the boundaries between speech and writing in the early Republic and in the America of Whitman's youth were not as absolute as we now take them to be.

In his earliest work on Leaves of Grass, it seems that Whitman, who was familiar with such ceremonies (he wrote articles about the local versions just after the publication of the 1860 edition), is trying to launch his work at the final stage of this process, to publish it as printed speech and so imply an oral genesis, or to project a text that would move fluidly into speech, drawing on the grammar of oratorical publication. And to this end, Whitman repeats Webster's translation of speech and writing-in his "Crossing Brooklyn Ferry." 16

Just as Webster addresses future generations via the monument, so Whitman moves to address future crossers through a landscape and its markings from the very beginning:

Flood-tide below me! I see you face to face!

Clouds of the west-sun there half an hour high-I see you also face to face.

Crowds of men and women attired in the usual costumes, how curious you are to me! On the ferry-boats the hundreds and hundreds that cross, returning home, are more curious to me than you suppose. . . . (11. 1-4)

In the first two lines, sensory observation is expressed as apostropheto the "flood-tide" and "Clouds" and "sun"-fusing visual and voca- 
tive address, so when Whitman's speaker extends his survey, in line three, to discover the "Crowds," where the attention to attire indicates a primarily visual apprehension, he is already also talking to them. The negotiation of scenic information directly facilitates interaction with fellow riders. When in the very next line the speaker turns to address "you that shall cross from shore years hence" (1. 5), the confusion of verbal and visual approach has been so fastened that the redirection of the apostrophe demands the presence of these future crossers who are seen through the landscape of the ferry course.

The speaker explains, in the poem's second section, how this seeing proceeds from the stability of the scene-the harbor, the ferry, the cities, and the people themselves. Here, his observations of the "scheme" catalyze a recognition of "The similitudes of the past and those of the future," that is, a surety about the similarity of the present to the past and of the future to the present. Once the stability of the scene, including the ferry and its act, are established, then a consideration of future crossers is no more a temporal over-extension than predicting the tides or the rising of the sun (11. 7-8). Where speaking and seeing are so welded, such predictions must expand the range of address by extending observational knowledge; it only makes sense then that in the poem's most substantial sections, the speaker reaches his audience through observations of the shared environment:

Just as you stand and lean on the rail, yet hurry with the swift current, I stood yet was hurried,

Just as you look on the numberless masts of ships and the thick-stemm'd pipes of steamboats, I look'd. (11. 25-26)

As the stability of the scene enables the speaker's vision, it also prepares his auditors to receive and accept this vision. These comparatives, like all those in the poem's third section, imagine the receiver's perception in the present tense and address the recipient at that moment-a moment in which that perception, like that of the speaker, may be extended to an apprehension of the other. In other words, the receiver may, like the speaker, see the other through the landscape, the very medium through which and out of which the speaker encourages this. Since Whitman and his audience connect through the landscape, it is continuously required, as is the concluding section of prayer, for permanence:

Flow on, river! flow with the flood-tide, and ebb with the ebb-tide!

Frolic on, crested and scallop-edg'd waves!

Thrive, cities - bring your freight, bring your shows, ample and sufficient rivers, Expand, being than which none else is perhaps more spiritual,

Keep your places, objects than which none else is more lasting. (11. 101-102, 123125) 
Just as Webster invests the Bunker Hill Monument with sentiments he hopes will be communicated to others, particularly those of later generations, so Whitman invests the harbor scene and the ferry with his testament to commonality and connection, which he conveys to future crossers (auditors, readers) through the same scene. As in Webster's address, in Whitman's poem the landscape functions as a connective medium, a medium capable of receiving, maintaining, then transmitting or reproducing force, presence. The landscape is something like an eardrum - or a sign. The monument-Webster's column or Whitman's ferry in its harbor course-is the sign; each imitates language, embodying, and later re-transmitting, the thought of each speaker.

Whitman's text, like Webster's, participates in this communication, though it is not simply a transcription of an original utterance or event, or as an extension of it. Whitman's text is situated within the monumental space and fused into the act of communication. The text appears briefly (and perhaps obscurely) in section 8, when Whitman's speaker asks: "What gods can exceed these that clasp me by the hand ... ?" (1. 95). Whitman here leans on the trope that shapes "Whoever You Are Holding Me Now in Hand," a poem that appears in the 1860 Leaves of Grass, in the section immediately preceding "Crossing Brooklyn Ferry." 17 In "Crossing Brooklyn Ferry" the book appears in its metonymy, the hand. The book is a metonymy of writing, as handwriting, which is a metonymy of the hand, where hand is a metonymy of the writer. Whitman's presence is transmitted along this line of metonymic substitution to appear in the poem as it is being read, even as his presence is also being transmitted by the ferry and its landscape to which the poem refers. So the text doubles the monument's act. And since the text appears within the monumental space, without being assigned a separate temporal signature, it is acting with, as well as within, the space to complete a primary communicative circuit; that is to say that it functions primarily, in its first instance, and not as a repetition.

The speaker helps build this sense of immediate occurrence as he imagines his readers individually, as he speaks directly to them, and as he builds the address around their present. The speaker uses the second person pronoun and parallel phrasing to imagine his readers as individuals. Though the extensively used "you" has an antecedent- "you men and women of a generation, or ever so many generations hence" (1. 21) - it is quickly effaced; while the antecedent is given four timesonce each in lines 3, 4, and 5, and finally in line 21 -it disappears altogether fairly early in the poem, to be replaced by sixteen instances of the pronoun, often in phrases that encourage one to construe it singularly. The speaker's declaration, "Just as any of you is one of a living crowd, I was one of a crowd" (1.23), prepares the way by disintegrating the crowd into its members, its ones; any further comparative in which correspondent phrasing indicates correspondent experience-take "Just as you 
are refresh'd by the gladness of the river and the bright flow, I was refresh'd" (1.24) for example-will encourage reading a correspondence of number between the "you" and the "I," making the "you" singular and specific to each reader. Thus the speaker prepares each reader for a specifically-directed communication which cannot be repeated until that reader, him- or herself alone, has received it once before. Every reader gets a chance to get it a first time.

To strengthen this context for immediate reception, the speaker continuously demands his readers' attention, recalling each one to the business at hand through the repeated and strategic deployment of the "you," as if to clarify its intended direction toward the auditor-reader and to continually renew the receivership. While the speaker does indulge in some fairly lengthy passages of self-referential description, each one closes with a directed reference to the auditor. Where section three closes with twenty-one lines that are focused on the speaker's experience, with no reference whatsoever to the auditor, section four opens with a declaration that reconnects speaker and auditor: "These and all else were to me the same as they are to you" (1.49). Again, section five is taken up mostly with the speaker's talking about himself - "I too lived, Brooklyn of ample hills was mine" (1. 57) - but the following section opens by redirecting attention to the other: "It is not upon you alone the dark patches fall" (1.65). Each return recasts the "you," the auditor-reader, as recipient, never allowing the suggestion of directed, dedicated communication to flag for long.

The poem effectively creates an arena for immediate reception by locating the auditor-reader in a never-altering present, one that encourages readers to perceive all action as occuring in their own time. This textual present forms a stable frame in which the speaker's recurring approach underscores the reader's role as recipient. Where the reader is said to "feel" (1.22), to receive the "fall" of the dark patches (1. 65), and to "have" a thought of the poet (1.87), the speaker keeps moving, changing in his temporal relation to the reader. The speaker's present tense in the first section- "I see you face to face" (11. 1, 2) - gives way to an indefinite tense in the second-"The impalpable sustenance of me from all things at all hours of the day" (1. 6) —and, in the third, passes through the present tense into the past- "I am with you, you men and women of a generation, or ever so many generations hence, / Just as you feel when you look on the river and sky, so I felt" (11. 21-22). The speaker casts his own acts in the past tense for three more sections- "I loved well those cities" (1. 50); "I too walk'd the streets of Manhattan island" (1. 58); "I too knitted the old knot of contrariety" (1.71). But in the seventh, he returns to a present tense and stands in the same time as the reader: "Who knows, for all the distance, but I am as good as looking at you now, for all you cannot see me?" (1.91). So the speaker moves toward the reader or auditor throughout the poem, striving to occupy the same 
temporal frame as the reader or auditor, while the reader or auditor is denied the same movement. The reader must then receive the speaker's declarations and advances at the moment of hearing or reading. The highly specific imagination of reader and rider focuses everything onto the receiver's moment and solidifies that moment as a present; all other temporal deictics are removed from the vicinity of the recipient position so that the poem militates against any sense of repetition on the part of the reader or auditor. And since the terms of address could apply equally to an auditor or a reader, the poem fuses the two, reducing all receptions to a single moment - the moment when "you" hear or read the poem.

Here Whitman seems to have learned from Webster and other epideictic orators that language can perform even when reception does not occur at the exact instant of transmission. Richard Ohmann (drawing on the work of J. L. Austin and John Searle) and others have denied literature performative and illocutionary force, declaring literature inherently representational, neither direct nor immediate and therefore incapable of fulfilling the most important felicity conditions on illocution, namely immediate mutual presence. ${ }^{18}$ But commemorative oratory (in its printed as well as spoken or performed forms) is not so restricted: since these addresses worked primarily to constitute meaning, to produce a particular knowledge and understanding (and not to create a specific ethical contract in which the actors' roles must be defined and performed, all roles here being identical, each participant as understander), ${ }^{19}$ they necessarily worked on those who, not present at the original pronouncement, received the logic for the first time-even as any of us is acted upon and changed by reading for the first time the definition of a word not yet understood. The conveyance of knowledge, it seems, is not dependent on mutual presence, but rather on the strength of both the conveyor's and the recipient's effort. Knowledge can withstand delay. Since the most important work of Webster's 1825 address is to fix not the meaning of the monument but of the nation and of the Revolution which the monument indicates, the address may act effectively on those who, not present at the first performance, read it for the first time, for it is then that they receive the argument, then that they may internalize it and alter their understanding of America, then that they may be changed. Webster endorses such delayed, gradual, and eventual transformation in his insistence that the American people, both of his time and later eras, replace and become the monument themselves.

Whitman's poem, like Webster's oration, seeks mainly to convey an understanding, an argument about the state of things and being that could change the character of the nation and its citizenry from within. One of the poem's crucial stanzas emphasizes this: 
We understand then do we not?

What I promis'd without mentioning it, have you not accepted?

What the study could not teach-what the preaching could not accomplish is accomplish'd, is it not? (11. 98-100)

Whitman's argument is simpler than Webster's, contending primarily that the past and the present are essentially the same, and that the future will be essentially the same as the present and the past, so that human history (and American history in particular) will have unity. But the argument is so fundamental, it does not require an immediate mutual presence in order for it to be completed, in order for it to act on its receivers. It proceeds as truth rather than act. It can endure delay. And since, as an argument about America, later generations would need to learn it too, its success is predicated on its ability to endure delay.

The book, then, is superior to oration alone. In the context of nineteenth-century oratory, the text is established as an effective structure of delay that does not radically diminish the content of the communication. According to Webster, the printed word is more powerful than the edifice: "no structure," he declares, "shall . . . outlive the duration of letters and knowledge among men." ${ }^{20}$ In Whitman's hand the text's reliquary powers are extended as it becomes a metonymic extension of him and his presence. So the text can extend his presence over time to effect the argument. Thus in Whitman's practice, oration and publication become fused, and print publication becomes no longer an addition to the oratorical moment but a part of it instead.

Webster's address, as an exemplar of commemorative oratory in the early Republic, provides a context within which Whitman's hope and practice of combining speech and writing become grounded. And it is an appropriate contextualizer. Though there is as yet no direct evidence of Whitman's familiarity with Webster's 1825 address, indirect connections abound. Webster's address and the ceremony of which it was a part became archetypes for a national rite instantiated in very different places at very different times in the nineteenth century. As a journalist, Whitman recalls on several occasions a ceremony, witnessed in youth, for the laying of a cornerstone for a library in Brooklyn; the liturgy as Whitman describes it is nearly identical to that of commemorations at Concord and at Bunker Hill in 1825, at Concord in 1837, at Bunker Hill in 1843, at Danbury, Connecticut, in 1854, and at Worcester, Massachusetts, in 1861 among others, and it is also remarkably similar to ceremonies marking the laying of the cornerstone for the Boston Public Library in 1855 and those held to celebrate the completion of the Washington Monument in 1883. Webster's speech remains one of the most famous and influential addresses of its kind and of its period, perhaps in part to its wide publication, and as such it seems likely that Whitman, as interested as he was in public speech and oratory in 
particular, would have been familiar with it. But even if he did not read it himself, he could have indirectly absorbed its rhetorical and liturgical lessons through his familiarity with the commemorative form it exemplifies. $^{21}$

As instructive as it is, this history only partly suggests the reasonableness of Whitman's desire for a combination of oral and scriptural modes. The articulations of his poetic program in the poems and the prose indicate the particular utility of such a combined mode, capable of preserving the poet's presence. Whitman makes clearest in Democratic Vistas and in his 1872 Preface to "As a Strong Bird on Pinions Free" that one of his major concerns is a reconciliation between the rights of the individual and the strength of the collective. In Democratic Vistas he puts it this way:

We shall, it is true, quickly and continually find the origin-idea of the singleness of man, individualism, asserting itself, and cropping forth, even from the opposite ideas. But the mass, or lump character, for imperative reasons, is to be ever carefully weigh'd, borne in mind, and provided for. Only from it, and from its proper regulation and potency, comes the other, comes the chance of individualism. The two are contradictory, but our task is to reconcile them. ${ }^{22}$

\section{And in more political terms:}

The idea of perfect individualism it is indeed that deepest tinges and gives character to the idea of the aggregate. For it is mainly or altogether to serve independent separatism that we favor a strong generalization, consolidation. As it is to give the best vitality and freedom to the rights of the States, (every bit as important as the right of nationality, the union,) that we insist on the identity of the Union at all hazards. ${ }^{23}$

Accommodating both positions is a logical problem, and the negotiation has lasting philosophical and aesthetic consequences for Whitman, as is evident in these prose excerpts. But the problem is particularly poignant in 1856 and 1860, sharply informing his work on the second and third editions. In "Proto-Leaf" (later "Starting from Paumanok"), the new initial poem for the 1860 Leaves of Grass, Whitman declares his effort toward solving this difficulty:

I will make a song for These States, that no one State may under any circumstances be subjected to another State,

And I will make a song that there shall be comity by day and by night between all The States, and between any two of them,

And I will make a song of the organic bargains of These States-And a shrill song of curses on him who would dissever the Union . . . . ${ }^{24}$

According to Kerry Larson, Whitman's work on the earliest editions of Leaves of Grass responds directly to "the constitutional crisis over slavery, revived with the introduction of the Wilmot Proviso in 1846, accelerated with the passage of the Fugitive Slave Law in 1850, and sealed 
with the Kansas-Nebraska Act in 1854 and Dred Scott in 1857." Whitman developed and redeveloped Leaves of Grass in a time in which, as Betsy Erkkila writes, "the American Union was itself dissolving." 25 But "Proto-Leaf" was only part of Whitman's response to this crisis.

In "Crossing Brooklyn Ferry" Whitman speaks directly to what Erkkila calls "the experience of fracture, anomie, and doubt that lay just beneath the rhetorical grandness of the poem's 'well-joined scheme."” The poem is not, however, simply troubled or even ambivalent. The "mixture of success and failure, adequacy and inadequacy" Samuel Beer finds in the poem is part of a delicate balance between the imagination of a democratic collective and the possible future of disintegrated individuals - a balance strongly endorsed by the retitling of the poem in 1860. The title "Crossing Brooklyn Ferry" makes the act of crossing, where travel makes intersection and interaction possible, more important than the hour or the various latenesses rendered crucial by the initial title, "Sun-Down Poem." With pessimistic suggestions of night-fall and the rain of dark patches toned down, the poem becomes an arena for investigating the tension between the competing political principles and for proposing what Erkkila calls "dramatic interaction" that could balance these principles and maintain the possibility for reconciliation. ${ }^{26}$

The writing in "Proto-Leaf" and the later prose from Democratic Vistas and the 1872 Preface show Whitman's position that the future of the American Union depended on such balance. In these formulations, the individualist, or State's rights position, requires absolute self-authorization and self-direction, the consistent and unassailable integrity of the one, while the collectivist, or Unionist position, requires that each one be reducible to a position within the collective. The tension here is between radically egalitarian democracy, in which presence is the base condition, and republican government, in which representation is an operative necessity. Where the 1860 "Proto-Leaf" diagnoses the difficulty, the newly retitled "Crossing Brooklyn Ferry" attempts a solution in its fusion of oral and scriptural modes. If speech - the medium of presence-might be coordinated and combined with writing - the medium of representation - if individual presence could be preserved even in representation, then republicanism might not threaten democratic principle and spirit, and the individual might safely participate in the union without relinquishing his or her own important power. Furthermore, if presence can be preserved within representation and extended over time, if it can endure delay and persist in representation, then the last barrier to a true egalitarian order-the superance in temporal progression-might be removed, and Americans might enjoy both unthreatened individualism and a stable and enduring secular union of empowered and liberated individuals.

Attempts to subvert death are numerous in Whitman's poetry, and most have been discussed extensively, though such subversions are usu- 
ally taken to indicate a crisis of confidence, of poetic power. ${ }^{27}$ But within Whitman's larger program, these avoidances seem to have a political dimension. However large a threat death is to Whitman's poetic powers, it is also a threat to his political power, since it would mean the removal of that power, the demolition of his individuality. And since egalitarian democracy is based on the power of the one, death may threaten the democratic order.

Whitman's imagination of "the public assembly" in the midst of "Crossing Brooklyn Ferry" seems particularly important in this regard. The assembly appears as Whitman removes himself: "[I] Saw many I loved in the street, or ferry-boat, or public assembly, yet never told them a word" (1. 81). Here, the power of the one exists unassailed even in its desuetude, retains standing in the collective even if it does not assert itself. Whitman's speaker enjoys access to the public assembly, as to the street and ferry-boat, even if he does not interact with others. And if this is the case, perhaps Whitman could retain his political power, that is his presence, even in death.

The desire is further clarified by a passage in "Starting from Paumanok," or "Proto-Leaf." There Whitman famously directs his readers:

See projected, through time,

For me, an audience interminable.

With firm and regular step they wend-they never stop,

Successions of men, Americanos, a hundred millions,

One generation playing its part and passing on,

And another generation playing its part and passing on in its turn,

With faces turned sideways or backward toward me to listen,

With eyes retrospective toward me. ${ }^{28}$

The concern with "generations" resonates with that in "Crossing Brooklyn Ferry," and the imagination here is much the same as that of the public assembly in the other poem. Whitman stands apart, so that he must be seen off to the side or behind, but he demands the respect of the generations future and past. The temporal order, in which one moment is superseded and replaced by another, is refigured spatially so that all relations become viewable and measurable along a common plane. So, Whitman cannot be supered by any one, past or present: he has extended the reach of democracy. Whitman performs a similar operation in the closing lines of "Song of Myself," where Whitman spatializes himself and does not pass on or by, but waits, in the space so later Americans never erase him. Time can provide no one with an advantage.

Perhaps this is what Whitman means when he declares in "Crossing Brooklyn Ferry" that "time avails not." According to the $O E D$, "avail" 
indicates "advantage" 29 ; to avail oneself of something it to take the advantage it offers. So perhaps Whitman declares not that time and place are meaningless, but rather that neither time nor place can give anyone advantage over any other-a declaration that would secure the condition of democracy, radical and inalienable equality. All people in all times, as well as in all places, would be equal to one another, have equal right and claim.

Whitman's declaration makes more difficult and more important the burden of memory shouldered in orations such as Webster's 1825 Bunker Hill address, for if Whitman is right, then we are required to respond to the needs of the past and to consider the rights of the dead as well as the demands and rights of the living. This is a central idea in another address delivered in 1825, Edward Everett's oration at Concord, Massachusetts, delivered two months before Webster's Bunker Hill address. Everett explains the work of monument thus:

... their blood calls to us from the soil which we tread; it beats in our veins; it cries to us, not merely in the thrilling words of one of the first victims in the cause,- ' $M y$ sons scorn to be slaves;'- but it cries with a still more moving eloquence,-'My sons, forget not your fathers. ${ }^{30}$

Everett requires his fellow Americans to heed the demands of the dead who persist in the soil that contains their blood and bodies. The notion of persistence is similar to Whitman's, as is the obligation the present has to the past. The persistence creates and maintains the obligation. And monuments, which answer the obligation, seek to inscribe both the persistence and the concomitant obligation more visibly upon the physical and cultural landscape. And the resultant compounded obligation, even as it strengthens the American narratives Webster and Everett and Whitman purvey, solidifies the base condition of democracy, a radical and irreducible equality.

In the America of 1860, Whitman could well have found in such egalitarian radicalism part of a solution to the constitutional crisis. Such extensive application of egalitarianism would certainly have participated in arguments against chattel slavery on the basis of universal equality and would have added to one point of conflict. But at the same time it could have removed an important philosophical point of conflict by protecting the kind of individualism that underwrites a State's-rights position. Quite elegantly, this move would make the State's-rights argument the strongest one against slavery, and if such intellection could not eliminate sectional conflict, it might have quickened into the cultural dialogue Whitman engages in his later prose.

Whitman writes in "Crossing Brooklyn Ferry" that his "sustenance" is "impalpable" and "from all things at all hours of the day." And though in the poem Whitman's attention seems focused on the harbor scene, one might well include the commemorative oratory of Webster, Everett, 
and others, as well as the crisis of union, in the list of impalpables, for the effect is clear: such events and such practices literally fed Whitman. The nutrition is more extensive than I have been able to suggest in the space of this essay. It is intriguing that in the time of the greatest crisis of American Union, Whitman employs the grammar of monumental utterance developed first by Webster and Everett to consolidate national sentiments in the years after the War of 1812, when human connections to the principles of the Revolution - veterans - were slowly disappearing. Like Webster at Bunker Hill and like Everett at Concord, in "Crossing Brooklyn Ferry" Whitman seeks to remind his fellow crossers and all Americans metonymically represented therein of the great possibilities for Democracy. ${ }^{31}$ And Webster's command, "... let the earliest light of morning gild it," rhymes so neatly with the tone of Whitman's own commands to the river and other elements of the harbor scene in the concluding section of "Crossing Brooklyn Ferry," undertaken for similar effect, surely there is more to be said about the enduring grammar of monumental utterance in nineteenth-century America and its effect on Whitman.

While time and place may not "avail," may not give anyone an advantage over any other, time and place do remain important to our understanding. In our own time, the cases against the fusion of speech and writing, or against the primacy of writing, or against a doctrine of presence in writing, may seem closed. But while our understanding does often produce some usefully detailed analyses, whether or not our current understanding is accurate for our time or for others as well is to an extent irrelevant in reading Whitman, in understanding the poet's work. Whitman, it seems, like Webster, found the notion of a fusion of speech and writing useful. Whitman, like Webster, seems to have developed both a functional theory about the ideal relation between speech and writing and a practice whereby to realize that relation. And it is this we must look for, this we must keep in mind when we read to understand Whitman's practice. Then time and place will avail, will give us an advantage not over him but with him, and we will better read Whitman in his time as he suggests he reads us in ours.

\section{University of Colorado-Denver}

\section{NOTES}

1 Leaves of Grass, Comprehensive Reader's Edition, ed. Harold W. Blodgett and Scully Bradley (New York: New York University Press, 1965), 160, 1. 20; 162, 1. 56. Citations from this poem will be subsequently referenced parenthetically by line number. 
2 James E. Miller, Jr., Walt Whitman (New York: Twayne, 1962), 97-98; James E. Miller, Jr., A Critical Guide to Leaves of Grass (Chicago: University of Chicago Press, 1957), 80; Paul Orlov, "On Time and Form in Whitman's 'Crossing Brooklyn Ferry," Walt Whitman Quarterly Review, 2 (Summer 1984), 12; James Gargano, "Technique in 'Crossing Brooklyn Ferry': The Everlasting Moment," fournal of English and German Philology 62 (April 1963), 262ff; Richard Pascal, "What Is It Then Between Us?': 'Crossing Brooklyn Ferry' as Dramatic Meditation," 1980: Leaves of Grass at 125, ed. William White (Detroit: Wayne State University Press, 1980), 60; Roger Gilbert, "From Anxiety to Power: Grammar and Crisis in 'Crossing Brooklyn Ferry,"” Nineteenth-Century Literature 42 (December 1987), 342.

3 In his article "The Written Orator of 'Song of Myself," Walt Whitman Quarterly Review 3 (Winter 1986), 1-12, Bauerlein's critique of Whitman's drive for orality draws primarily on the work of J. L. Austin, Richard Searle, and Richard Ohmann to find impossible the hope for a poetics of presence he reads in the oral signatures of Whitman's work. The base of the argument is the idea, developed in the speech-act theory of these critics, that literature is basically representational and therefore never immediate; accordingly, any literary orality (and perhaps any oral literature) cannot be characterized as fully immediate. According to Bauerlein, Whitman's orality is stylized and premeditated, simply a representation or suggestion of true orality. While supported by speech-act theory, Bauerlein's critique extends beyond its bounds into the territory of Derridean critique when Bauerlein redresses Whitman for the naivete of his wish for orality.

The Derridean premise of the primacy of writing is more operative in Tenny Nathanson's Whitman's Presence (New York: New York University Press, 1992). For Nathanson, Whitman's "verbal gestures" are simple "gestures," and the voice is never voice but an "image of voice." Writing is only writing, from the very beginning of Nathanson's critique. So he can state, with absoluteness, early on: “All Whitman's most dramatic verbal gestures . . . finally situate themselves in . . . [the] gap [between the poet and his 'divine origins']. The words of Whitman's book recall a magical power they cannot re-capture or re-activate: deriding the merely representational function of ordinary language and seeking to reclaim some power of the word as magical act, Whitman's poems occupy the sometimes comic, often melancholy space in which such archaic performative power is itself represented rather than acted" (14, emphasis added).

Nathanson's and Bauerlein's denials of performative power to written language are in line with speech-act and Derridean linguistic theory. But the Derridean proscription is more severe, since it ultimately rises from the Sausurrean tenet that the signifier is always representational, according to which performative power cannot inhere in language.

4 Bauerlein, 12.

5 Bauerlein, 12.

6 F. O. Matthiessen, American Renaissance (New York: Oxford University Press, 1941), 22.

7 See C. Carroll Hollis, Language and Style in Leaves of Grass (Baton Rouge: Louisiana State University Press, 1983), 28-64.

8 Daniel Webster, "An Address Delivered at the Laying of the Corner-Stone of the Bunker Hill Monument at Charlestown, Massachusetts, on the $17^{\text {th }}$ of June 1825," Great Speeches and Orations of Daniel Webster, ed. Edwin Whipple (Boston: Little, Brown, \& Co., 1889), 124. 
9 Webster, 125-126.

10 Webster, 128; 135, emphasis added.

11 Irving Bartlett, Daniel Webster (New York: Norton, 1978), 110.

12 Craig R. Smith, Defender of the Union: The Oratory of Daniel Webster (New York: Greenwood Press, 1989), 28.

13 Edwin Whipple, Great Speeches and Orations of Daniel Webster (Boston, Little, Brown, \& Co., 1889), 136.

14 Pauline Maier, American Scripture: Making the Declaration of Independence (New York: Random House, 1988), $158 \mathrm{ff}$.

15 Accounts of the ceremony at Concord, Massachusetts, July 4, 1837, were carried in many local newspapers, including the Yeoman Gazette, in which an article from July 8,1837 , includes a list of prayers and addresses delivered at the event and the full text of Emerson's "Concord Hymn" which, the article claims, "speaks for itself, and at once excites the ideas of originality, poetic genius, and judicious adaptation." The photocopy of the text of this article was provided to me by librarians at the Minuteman Public Library in Concord, Massachusetts. See also Ralph Rusk, The Life of Ralph Waldo Emerson (New York: Scribner's, 1949), 274.

Accounts for the other ceremonies mentioned here were published as pamphlets now available on microfilm in University Microfilm International's series of Pamphlets in American History. The pamphlet for the Danvers ceremony is catalogued as RW 47, that for the Danbury ceremony as RW 103, that for the Worcester ceremony as RW 347, that for the Doylestown ceremony as 237. Webster's 1843 Bunker Hill address was published by three different publishers and may be found in the Pamphlets in American History as RW 176, RW 327, and RW 359.

For a fuller treatment of the development of this secular liturgy, see Jake Adam York, The Architecture of Address: The Monument and Public Speech in American Poetry (Dissertation, Cornell University, 2000), 19-34.

16 I have in mind here Whitman's "Brooklyniana," collected by Henry Christman in Walt Whitman's New York (New York: Macmillan, 1963). In these columns, Whitman treats Brooklyn's celebration of July $4^{\text {th }}, 1825$, at which General Lafayette, who had also attended Webster's Bunker Hill address and Edward Everett's Concord Address in the months previous, was present. See Christman, 61-65, 121-127. According to Justin Kaplan, Whitman had written of the same event earlier, in the Brooklyn Daily Times in 1857. See Justin Kaplan, Walt Whitman: A Life (New York: Simon and Schuster, 1980), 65. That Whitman wrote about the event on three separate occasions is testimony to his sense of its importance. But even more relevant to the present demonstration is that two of those occasions came in 1861, so close after the publication of the 1860 Leaves of Grass. If the event is on Whitman's mind less than a year after the 1860 Leaves appears, it may well have been on his mind before.

17 See table of contents for the 1860 Leaves in Leaves of Grass: A Textual Variorum of the Printed Poems, ed. Sculley Bradley, Harold W. Blodgett, Arthur Golden, William White (New York: New York University Press, 1980), 2:271-272.

18 Bauerlein, 9-12; Hollis, 65-123; Richard Ohmann, "Speech Acts and the Definition of Literature," Philosophy and Rhetoric 4 (1971), 1-19.

19 I am thinking here of Searle's major example in Speech Acts (Cambridge University Press, 1969), namely the promise. Many of Austin's examples, including a marriage, have a similar quality. Both philosophers are primarily concerned with acts that involve speech. Webster's work, and Whitman's, it seems to me, is such that speech is 
act, that the two are confused; in these cases the speech carries the act and is not simply one component in an entire field of action.

20 Webster, 125.

21 See notes 8 and 15, above.

22 Prose Works 1892, ed. Floyd Stovall (New York: New York University Press, 1964), 2:373.

$23 P W, 2: 374$.

24 LG Var., 2:277.

25 Kerry Larson, Whitman's Drama of Consensus (Chicago: University of Chicago Press, 1988), xvii; Betsy Erkkila, Whitman the Political Poet (New York: Oxford University Press, 1989), 143.

26 Erkkila, 141; Samuel Beer, "Liberty and Union: Walt Whitman on American Community," New Republic (January 23, 1984), 30. Erkkila's commentary on the decoration of the 1860 Leaves of Grass with symbols of balance suggests that Whitman's retitling of "Crossing Brooklyn Ferry" may, among other things, coordinate the poem with the new edition. According to Erkkila, the "cloud-globe and sun-sea images that enclose the poems are . . . ambiguous: The globe may be passing out of or being engulfed by a cloud, and the sun may be rising out of or falling into the sea. .." (156157). At that point it was difficult to foresee exactly whether the union would have emerged from or became engulfed in the conflict over slavery and political philosophy. It was, therefore, important for "Crossing Brooklyn Ferry" as well as the entire 1860 Leaves of Grass to acknowledge the difficulties while maintaining hope: thence the balance.

27 See particularly Roger Gilbert, cited above in note 1.

28 LG Var., 2:274-275.

29 The Compact Oxford English Dictionary, $2^{\text {nd }}$ Edition (Oxford: Clarendon Press, 1991), 2210.

30 Edward Everett, "Oration Delivered at Concord, April 19, 1825," Orations and Speeches, on Various Occasions (Boston: American Stationers' Company, 1836; rpt. New York: Arno Press, 1972), 69-70.

31 For a more extensive treatment of this topic, see York, The Architecture of Address, 34-123. 